\title{
A Study on the Competence of English Subject at Junior Middle School Having Low and High Order Thinking Skills
}

\author{
Fauris Zuhri \\ English Department \\ Universitas Negeri Surabaya \\ Surabaya, Indonesia \\ fauriszuhri@unesa.ac.id
}

\author{
Susanto \\ English Department \\ Universitas Negeri Surabaya \\ Surabaya, Indonesia \\ susanto@unesa.ac.id
}

\begin{abstract}
The purpose of this paper is to find out which contents of core and basic competence of English subject have low-order thinking skills (LOTS) and higher-order thinking skills (HOTS) at Junior Middle School. It discusses that learning taxonomies having six levels: remembering, understanding, implementing, analysing, assessing, and creating. The levels of taxonomies are classified by two kinds of groups. The first three groups is low-order thinking skills (LOTS), and the second three groups is higher-order thinking skills (HOTS). Higher-order thinking skills (HOTS) have characteristics: transferring knowledge, critical thinking, and problem solving. This research applied a case study method. The result of study showed that the content standard of 2013 Curriculum only differentiated competence into knowledge competence and skill competence, whereas Bloom's taxonomy used as its development reference consisted of six levels of taxonomies. And also the content of core competence and basic competence are inconsistent with Bloom's taxonomy.
\end{abstract}

Keywords - learning taxonomy; low-order thinking skills (LOTS); higher-order thinking skills (HOTS); core competence; and basic competence.

\section{INTRODUCTION}

This paper delivers explanation of LOTS: low-order thinking skills, HOTS: high-order thinking skills, and taxonomy of learning. In learning teaching activities, a teacher plays an important role. There are some steps to conduct learning teaching activities; the first step is that a teacher should perform well in conducting learning and teaching activities in order to determine what the learning objectives are. Relates to objectives of learning, there are several definitions of them in some literatures. First, the purpose of learning is defined as the behaviour of learners that show how leaners have mastered the knowledge and skills by activities of learning [1]. The objectives of learning are also defined as a description of the knowledge and skills which are shown by learners who can be declared as a competence when they are studying [2] . In addition, the objectives of learning are also defined as the expected outcomes of learning activities, which are formulated in such a way so learners' acquisition or deficiency can be observed and measured [3]. Gagne [4] also mentioned that the purpose of learning is a statement of the final outcomes of learning activities concerning learners' knowledge and skills, in which the statement mentioned the specification of the situation to be observed. Four definitions of the objectives learning are similar; they mention and describe the outcome of a teaching, not the process of a teaching [2].

Learning objectives are crucial to formulate the basis of selection of subject matter of content, how to organize learning and teaching activities, and also how to evaluate the achievement of learning, and help students to have a planning of their efforts to achieve the knowledge and skills for a learning process [1]. In 2013 Curriculum, the objectives of learning are formulated in the Content Standard, namely, the scope of the material criteria and the level of competence in order to achieve the competence of graduates at a certain level and type of education [5]. The scope of the material criteria and the level of competence to achieve the competence of graduates are in this particular level of education and formulated in the form of basic competence. In syllabus and lesson plan, basic competence is translated into several indicators of achievement of competence. The problem is to which extent the formulation of basic competence in the Content Standards can be translated into indicators of achievement of competence that have LOTS and HOTS. Specifically, this paper is intended to examine to which extent the Content Standard of English of 2013 Curriculum contain the formulation of basic competence having LOTS and HOTS. Based on the findings, the content of core and basic competence having LOTS and HOTS are formulated and presented a method of basic competence formulation that is in line with LOTS and HOTS.

\section{METHOD}

This research is a case study research [6] or case study research [7]. The data of research are verbs used in the content of basic competence of English subjects of 2013 Curriculum in Junior Middle School. In this research, one document-data source-studied is a document of core and basic competence of English subjects of 2013 Curriculum in Junior Middle School [5]. This research is referred to as a case study research although the data source is only one document. Bogdan and Biklen mention that case studies are an in-depth study of one place/environment, one subject/person, one document collection, or one special occasion. 
According to the characteristics of the source of data, the data are collected by reading the documents carefully, reviewing the content of the document in depth, and making the data classification based on the research question. Researcher is a research instrument. The analysis is done by comparing the suitability and nonconformity of the data studied with the concept of the formulation of objectives of learning and the concept of LOTS and HOTS. The analysis concludes that the formulation of the findings and conclusions are.

\section{RESULTS AND DISCUSSION}

This part is going to deliver some points relates with results and discussion, as follows:

\section{High-Order Thinking Skills / HOTS}

HOTS are characterized by three kinds of forms of thinking skills, namely: transfer of knowledge and skills, critical thinking, and problem solving [8]. The explanation is, as follows: first, a skill is HOTS if it has a process and the skill is in the form of transfer (transfer). In level of transfer, learners do not only remember and understand the knowledge and skills they have learned, but they are able to interpret the knowledge and skills and use them in new situations. According to Brookhart, a skill is said as a transfer (or including HOTS) if the skill is capable to be done by students in the outside of school and in real life, or daily activities.

Second, HOTS are characterized by critical thinking skills. Critical thinking refers to have reasoning and reflective thinking in order to determine a belief and action [9]. Critical thinking is also an artful thinking that is in the process having submission activities reasons, questions and inquiries, observations and portrayals, comparisons and discovery of relationships, searching and viewing complexity [10]. So in critical thinking, learners are able to make wise and sustainable decisions.

Third, HOTS are also characterized by problem-solving skills; it means that a skill finding out solutions to a problem that cannot be solved only by memorizing [11]. It should be noted that not all activities of thinking are designed for learners and to solve problems are called problem solving. A skill is called a problem-solving skill if delivering problem requires thinking in order to find out a solution and the problem has several possible solutions. Learners do not know the specific solution at the beginning of the thinking process. In order to find out a solution, learners carry out a series of actions in the form of: recall the information they have learned and possessed, study the problems in order to gain an understanding, critically assess some problem-solving thoughts, formulate alternative unusual solutions, and communicate them completely, coherently, and effectively. Bransford and Stein [12] argue that problem solving is the thinking mechanism behind all thinking skills that include memorizing, critical thinking, creative thinking, and effective communicating. The thinking skills that do not contain transfer, critical thinking, and problem solving are not HOTS.

\section{Taxonomy of Purpose, LOTS and HOTS}

Bloom [13] developed a classification of intellectual behaviour in learning. Bloom's Taxonomy presents three objectives: cognitive, psychomotor, and affective. For the cognitive domain, Bloom identifies six levels of objectives: knowledge, understanding, application, analysis, synthesis, and evaluation, which are still used today for reference to the framework of identifying, selecting, formulating, and organizing learning objectives. This framework is very important for teachers as the basis for the formulation of learning objectives as it shows the sequence of thinking skills, as seen in the following figure:

\section{Bloom's Taxonomy}

\section{C6: Evaluation}

$\Delta$

C5: (Synthesis) (Evaluation)

$\Delta$

C4: Analysis

$\Delta$

\section{C3: Application}

$\Delta$

\section{C2: Understanding (comprehension)}

\section{C1: Knowledge}

Taxonomy of Bloom revised by Anderson and Krathwohl [14]. These two taxonomies are essentially the same-incarnate learning objectives. The difference lies in:

1) Bloom uses nouns (knowledge, understanding, application, analysis, synthesis, and evaluation) to group thinking skills, while Anderson and Krathwohl use verbs (remembering, understanding, applying, analysing, assessing, and creating);

2) Bloom uses the terminology 'synthesis' (noun), while Anderson and Krathwohl use the terminology 'creating' (verb) to refer to the same ladder;

3) Anderson and Krathwohl put the thinking skills of creating at the highest level 6, which on the Bloom taxonomy is at level 5. Meanwhile, the assessing downgraded to level 5.

Six levels of Boom intellectual behaviour or skills can be categorized into LOTS and HOTS groups (categories). LOTS is at the bottom three levels: knowledge/remembering, understanding/understanding, and applying/applying. Knowledge / remembering, understanding belong to the LOTS group (category) because this skill only expects learners to demonstrate their understanding of the facts and ideas they have learned, for example: the skills of organizing, comparing, 
translating, interpreting, explaining, and mentioning the main thoughts.

Remembering, understanding, and applying include LOTS because learners only use the knowledge, facts, techniques, rules, and/or conditions. Each of them does not involve transfer activities, critical thinking, and problem solving.

In contrast the three skills at the top in Bloom's taxonomy (or Anderson and Krathwohl) fall into the HOTS group (category). First, analytical skills require learners to study a unity (thing/stuff, idea, concept) and break it down into the parts that make up it. Learners are expected to be able to identify the purposes, explain the purposes, formulate conclusions, and show supporting evidence. Second, assessing skills require learners to present and retain a thought. Students are expected to be able to assess the information, validity of a thought, or the quality of a work based on a number of criteria. Third, the creating skill requires learners to organize some information into the form of a whole and new unit by combining several elements that have been studied. The skill of creating is also shown in the form of the skill of producing something in the form of an alternative problem solving.

Analysing, assessing, and creating involve transferring, critical thinking, and problem solving. Each skill, therefore, belongs to the HOTS group (category) because it involves transfer, critical thinking, and problem solving.

In order to formulate behavioural objectives, there are a number of action verbs, derived from Bloom's taxonomy (Table 1).

TABLE 1: SOME EXAMPLES OF ACTION VERBS BASED ON BLOOM'S TAXONOMY

\begin{tabular}{|c|c|c|c|}
\hline Level of & \multicolumn{3}{|c|}{ Action Verbs } \\
\hline Remembering & $\begin{array}{l}\text { Mention } \\
\text { Define } \\
\text { Shows } \\
\text { Identify }\end{array}$ & $\begin{array}{l}\text { Repeat } \\
\text { Revealed } \\
\text { Cite } \\
\text { Rewrite }\end{array}$ & $\begin{array}{l}\text { Write again } \\
\text { Mention } \\
\text { again } \\
\text { Make a list }\end{array}$ \\
\hline Understanding & $\begin{array}{l}\text { Associates } \\
\text { Classify } \\
\text { Comparing } \\
\text { Explaining }\end{array}$ & $\begin{array}{l}\text { Interpret } \\
\text { Report } \\
\text { Distinguish } \\
\text { Translating }\end{array}$ & $\begin{array}{l}\text { Review } \\
\text { Conclude }\end{array}$ \\
\hline Implementing & $\begin{array}{l}\text { Implementing } \\
\text { Demonstrate } \\
\text { Demonstrate } \\
\text { Using }\end{array}$ & $\begin{array}{l}\text { Practice } \\
\text { Translating } \\
\text { Writing/ } \\
\text { composing } \\
\text { Practicing }\end{array}$ & $\begin{array}{l}\text { Presenting } \\
\text { verbally } \\
\text { Read }\end{array}$ \\
\hline Analysing & $\begin{array}{l}\text { Analyse } \\
\text { Appreciate } \\
\text { Contrast } \\
\text { Comparing to }\end{array}$ & $\begin{array}{l}\text { Conclude } \\
\text { Questioning } \\
\text { Summarize } \\
\text { Splitting }\end{array}$ & $\begin{array}{l}\text { Detect } \\
\text { Create a } \\
\text { diagram }\end{array}$ \\
\hline Assessing & $\begin{array}{l}\text { Appreciate } \\
\text { Accessing } \\
\text { Choose } \\
\text { Recommend }\end{array}$ & $\begin{array}{l}\text { Assess } \\
\text { Reviewing } \\
\text { Choose } \\
\text { Checking }\end{array}$ & $\begin{array}{l}\text { Shows an } \\
\text { excess } \\
\text { Write a } \\
\text { review }\end{array}$ \\
\hline Creating & $\begin{array}{l}\text { Designing } \\
\text { Formulate } \\
\text { Plan } \\
\text { Designing }\end{array}$ & $\begin{array}{l}\text { Composing } \\
\text { Designing } \\
\text { Produce } \\
\text { Writing/ } \\
\text { Composing }\end{array}$ & $\begin{array}{l}\text { Creating } \\
\text { Write a } \\
\text { review }\end{array}$ \\
\hline
\end{tabular}

\section{Problems Related to the Frame of Core and Basic Competence in 2013 Curriculum and the Solutions}

This section presents the results of a review of LOTS and HOTS in the Content Standards and it will be discussed below: the results indicate that the absence of formulation of basic competence based on HOTS in it. Based on the findings, the framework of core and basic competence based on LOTS and HOTS and is continued by the method of formulation are going to be presented in the following discussion.

1) The Formulation of Basic Competence based on LOTS and HOTS

The formulation of competence and the scope of learning material for each unit of education is formulated in the form of Knowledge of Core Competence (Core Competence 3) and the formulation of Skills of Core Competence (Core Competence 4). The Knowledge of Core Competence is further elaborated into several formulations of Knowledge of Basic Competence and Skills of Core Competence are outlined into several Skills of Basic Competence formulas.

The elaboration of competencies only relates to the knowledge (core competence 3) and skills (core competence 4) indicate that the development of core competence and basic competence of documents in 2013 Curriculum is inconsistent with the regulation in Permendikbud stating that the reference for the development of this level of competence is Bloom's taxonomy, which was first introduced by a group of researchers led by Benjamin Bloom in 1956 and further developed by Anderson and Krathwol in 2001. In other words, the frameworks of core competence and basic competence do not consider the level of taxonomy.

The elaborations of competence of a cognitive competence into knowledge of core competence (core competence 3 ) and skill of core competence (core competence 4) are not only inconsistent with the regulation in Permendikbud, but also inappropriate, confusing, and raises many questions.

2) The Framework of Core Competence and Basic Competence based on LOTS and HOTS

If it is consistent with Bloom's taxonomy, the framework of core competence and basic competence of the cognitive domain should be formulated by listing the six levels of taxonomy: knowledge, understanding, application, analysis, synthesis, and assessment (Table 2).

TABLE 2: THE FRAMEWORK OF CORE AND BASIC COMPETENCE BASED ON BLOOM'S TAXONOMY.

\begin{tabular}{|c|c|c|c|c|c|}
\hline \multicolumn{6}{|c|}{ Core Competence } \\
\hline Knowledge & $\begin{array}{l}\text { Under- } \\
\text { standing }\end{array}$ & Application & Analysis & Synthesis & Assessment \\
\hline (1) & (2) & (3) & (4) & (5) & (6) \\
\hline$\cdots$ & $\cdots$ & $\cdots$ & $\cdots$ & $\cdots$ & $\cdots$ \\
\hline \multicolumn{6}{|c|}{ Basic Competence } \\
\hline Knowledge & $\begin{array}{l}\text { Under } \\
\text { standing }\end{array}$ & Application & Analysis & Synthesis & Assessment \\
\hline (1) & (2) & (3) & (4) & (5) & (6) \\
\hline$\cdots$ & $\cdots$ & $\cdots$ & $\cdots$ & $\cdots$ & $\cdots$ \\
\hline
\end{tabular}


Table 2 shows the existence of six levels of taxonomy that is a consistence with Bloom's taxonomy. The framework of core competence and basic competence contains the six levels of taxonomy: core competence and basic competence knowledge, core competence and basic competence understanding, core competence and basic competence application, core competence and basic competence analysis, core competence and basic competence synthesis, and core competence and basic competence assessment.

As discussing earlier, the skills are distinguished in two categories: LOTS and HOTS. LOTS includes three lower levels of Bloom's taxonomy, while HOTS includes three high levels of the same taxonomy. Based on the characteristics of LOTS and HOTS, six levels of taxonomy need to be classified. The three lower levels of Bloom's taxonomy are placed under the LOTS category and the top three levels are grouped under the HOTS category (Table 3 ).

TABle 3: The Framework of CORE COMPETENCE AND Basic COMPETENCE (BLOOM)

\begin{tabular}{|c|c|c|c|c|c|}
\hline \multicolumn{6}{|c|}{ Core Competence } \\
\hline \multicolumn{3}{|c|}{ LOTS } & \multicolumn{3}{|c|}{ HOTS } \\
\hline Knowledge & $\begin{array}{l}\text { Under- } \\
\text { standing }\end{array}$ & Application & Analysis & Synthesis & Assessment \\
\hline (1) & (2) & (3) & (4) & (5) & (6) \\
\hline$\ldots$ & $\ldots$ & $\ldots$ & $\ldots$ & $\ldots$ & $\ldots$ \\
\hline \multicolumn{6}{|c|}{ Basic Competence } \\
\hline & LOTS & & & HOTS & \\
\hline $\begin{array}{l}\text { Knowledge } \\
\text { (1) }\end{array}$ & $\begin{array}{l}\text { Understanding } \\
\text { (2) }\end{array}$ & $\begin{array}{l}\text { Application } \\
\text { (3) }\end{array}$ & $\begin{array}{l}\text { Analysis } \\
\text { (4) }\end{array}$ & $\begin{array}{l}\text { Synthesis } \\
\text { (5) }\end{array}$ & $\begin{array}{l}\text { Assessment } \\
\text { (6) }\end{array}$ \\
\hline$\ldots$ & $\ldots$ & \begin{tabular}{l|l}
$\ldots$ & \\
\end{tabular} & $\ldots$ & $\ldots$ & $\ldots$ \\
\hline
\end{tabular}

Table 3 above, on the other hand, it can answer the confusion and questions that have arisen in core competence and basic competence 2013 Curriculum. The framework of core competence and basic competence are in Table 5, facilitate an understanding of LOTS and HOTS and more importantly leads and limits clearly how basic competence (basic competence 4) is formulated. The following sections will explain them.

3) Formulation of Basic Competence having LOTS and Basic Competence having HOTS

The levels of taxonomy are used for the development of standard of competence of graduation is Bloom's taxonomy which is later developed by Anderson and Krathwol. The first difference is in the use of words: remembering, understanding, applying, analysing, assessing, and creating. The second difference lies in the levels of taxonomy. If Anderson and Krathwol's taxonomy are used as a reference, the framework of core competence and basic competence is going to appear as follows (Table 4):
TABle 4: THE FramewORK OF CORE COMPETENCE AND BASIC COMPETENCE (ANDERSON)

\begin{tabular}{|c|c|c|c|c|c|}
\hline \multicolumn{6}{|c|}{ Core Competence } \\
\hline & LOTS & & & HOTS & \\
\hline $\begin{array}{l}\text { Remember - } \\
\text { ing } \\
\text { (1) }\end{array}$ & $\begin{array}{l}\text { Under- } \\
\text { standing } \\
\text { (2) }\end{array}$ & $\begin{array}{l}\text { Apply- } \\
\text { ing } \\
\text { (3) }\end{array}$ & $\begin{array}{l}\text { Analys- } \\
\text { ing } \\
\text { (4) }\end{array}$ & $\begin{array}{l}\text { Assessing } \\
\text { (5) }\end{array}$ & $\begin{array}{l}\text { Creating } \\
\text { (6) }\end{array}$ \\
\hline$\cdots$ & $\cdots$ & $\cdots$ & $\cdots$ & $\cdots$ & $\cdots$ \\
\hline \multicolumn{6}{|c|}{ Basic Competence } \\
\hline \multicolumn{3}{|c|}{ LOTS } & \multicolumn{3}{|c|}{ HOTS } \\
\hline $\begin{array}{l}\text { Remember } \\
\text {-ing } \\
\text { (1) }\end{array}$ & $\begin{array}{l}\text { Under- } \\
\text { standing } \\
\text { (2) }\end{array}$ & $\begin{array}{l}\text { Apply } \\
\text { ing } \\
\text { (3) }\end{array}$ & $\begin{array}{l}\text { Analys- } \\
\text { ing } \\
\text { (4) }\end{array}$ & $\begin{array}{l}\text { Assessing } \\
\text { (5) }\end{array}$ & $\begin{array}{l}\text { Creating } \\
\text { (6) }\end{array}$ \\
\hline$\ldots$ & $\ldots$ & $\ldots$ & $\ldots$ & $\ldots$ & $\ldots$ \\
\hline
\end{tabular}

In 2013 Curriculum, knowledge of basic competence (basic competence 3 ) is formulated by using verbs identifying, understanding, comparing, applying, interpreting and skills of basic competence (basic competence 4) is formulated by using verb processing, rewarding, judging, and reasoning. This dichotomy has ignored the level of taxonomy, it is difficult to be understood, and has arisen multi-interpretation.

Empirical evidence indicates the fact that teachers, students, trainees, and training managers find difficulty to develop syllabus based on core competence and basic competence of 2013 Curriculum. The biggest difficulty lies in formulating Indicators of Competence Achievement (IPK). They do not have definite reference how basic competence is formulated into Indicators of Competence Achievement. They do not realize that to formulate Indicators of Competence Achievement based on the formulation of content of basic competence in the Content Standard is impossible. For example, one of content of basic competence 3 and basic competence 4 of English subjects in junior middle school are stated, as follows:

3.1 To identify social functions, text structures, and linguistic elements of spoken interpersonal and written interpersonal interactions involving acts of greeting, saying goodbye, giving thanks and apologizing, and responding to, in the context of their use.

4.1 To compose very short and simple interpersonal interaction text that involves greeting, saying goodbye, saying thank you, and apologizing, and responding to it by taking into account the correct and contextual function of social, text structure, and linguistic elements.

The problem with the content of basic competence above is the use of word is to identify (identifying) and to compose (composing) are already operational verbs. The operational verbs in the content of basic competence become the cause of the unfavourable indicators of achievement of competence that is formulated because the basic competence is actually already indicators of achievement of competence. For that reason, the analysis of basic competence is required so those indicators of achievement of competence can be identified [15].

The framework of core competence and basic competence are adapted from Anderson \& Krathwol's taxonomy and having LOTS and HOTS give solution to the problem of 
determining indicators of achievement of competence-one of the important syllabus components. The basic competence can easily be identified by some indicators of achievement of competence if its basic competence is formulated by using an appropriate verb in the taxonomy level. Basic competence Remembering is formulated with a verb remembering, basic competence Understanding is formulated with a verb understanding, basic competence Applying is formulated with a verb applying, basic competence Analysing is formulated with verb analysing, basic competence Assessing is formulated with verb assessing, and basic competence Creating is formulated by creating verbs (Table 5).

TABle 5: The Framework of CORE AND BASIC COMPETENCE

\begin{tabular}{|c|c|c|c|c|c|}
\hline \multicolumn{6}{|c|}{ Core Competence } \\
\hline & LOTS & & & HOTS & \\
\hline $\begin{array}{l}\text { Remember } \\
\text {-ing } \\
\text { (1) }\end{array}$ & $\begin{array}{l}\text { Under- } \\
\text { standing } \\
\text { (2) }\end{array}$ & $\begin{array}{l}\text { Apply- } \\
\text { ing } \\
\text { (3) }\end{array}$ & $\begin{array}{l}\text { Analys- } \\
\text { ing } \\
\text { (4) }\end{array}$ & $\begin{array}{l}\text { Assess- } \\
\text { ing } \\
(5)\end{array}$ & $\begin{array}{l}\text { Creating } \\
\text { (6) }\end{array}$ \\
\hline \multicolumn{6}{|c|}{ Basic Competence } \\
\hline & LOTS & & & HOTS & \\
\hline $\begin{array}{l}\text { Remember } \\
\text {-ing } \\
\text { (1) }\end{array}$ & $\begin{array}{l}\text { Under- } \\
\text { standing } \\
\text { (2) }\end{array}$ & $\begin{array}{l}\text { Apply- } \\
\text { ing } \\
\text { (3) }\end{array}$ & $\begin{array}{l}\text { Analys- } \\
\text { ing } \\
\text { (4) }\end{array}$ & $\begin{array}{l}\text { Assess- } \\
\text { ing } \\
\text { (5) }\end{array}$ & $\begin{array}{l}\text { Creating } \\
\text { (6) }\end{array}$ \\
\hline
\end{tabular}

To remember/understand/ apply the social function, text structure, and linguistic elements of spoken interpersonal and written interpersonal interactions involving acts of greeting, saying goodbye, saying thank you, and apologizing, and responding to, in the context of their use.

To analyse/assess/create very simple spoken and simple written interpersonal text interactions that involve greeting, saying goodbye, saying thank-you, and apologizing, and responding by paying attention to the correct and context-appropriate social function, text structure, and linguistic elements.

With the use of a verb remembering, understanding, applying, analysing, assessing, and creating in the formulation of basic competence, the indicators of achievement of competence $(I P K)$ of a basic competence can be formulated by selecting one of the action verbs corresponding to the level of taxonomy (see Table 1). Two or even three indicators of achievement of competence (IPK) can be formulated for one basic competence when they are needed (Table 6).

TABLE 6: THE FORMULATION OF INDICATORS OF ACHIEVEMENT OF COMPETENCE $(I P K)$

\begin{tabular}{lll}
\hline Basic Competence & $\begin{array}{c}\text { Indicators of Achievement } \\
\text { of Competence }\end{array}$ \\
\hline $\begin{array}{l}\text { To remember the social function, text } \\
\text { structure, and linguistic elements of spoken }\end{array}$ & - Mentioning ... \\
interpersonal and written interpersonal & - Identifying ... \\
interactions involving acts of greeting, & - Repeating ... \\
saying goodbye, saying thank you, and & - Showing ... \\
apologizing, and responding to, in the & & \\
context of their use. & & \\
To understand the social function, text & - Comparing ... \\
structure, and linguistic elements of spoken \\
and written interpersonal interaction texts \\
that involve greeting, saying goodbye, & - Describing ... \\
saying thank you, and apologizing, and & - Discussing ... \\
responding to, in the context of their use. & \\
\hline
\end{tabular}

The examples above are basic competence of Remembering and Understanding levels. For other Basic Competence levels, the selection of verbs is adjusted to the level of taxonomy.

\section{CONCLUSION}

The main problem in developing syllabus of the standard of Content of 2013 Curriculum comes from the formulation of content of basic competence is in 2013 Curriculum. The content standard of 2013 Curriculum only differentiates competence into knowledge of basic competence (basic competence 3) and skills of basic competence (basic competence 4), whereas Bloom's taxonomy used as a developmental reference consisting of six levels of taxonomy. As a result, the formulations of basic competence are inconsistent with the purposes of Bloom's taxonomy. The discussion has shown a mismatch between the core competence and basic competence of 2013 Curriculum. The frameworks of core competence and basic competence that is compatible with Bloom's taxonomy and having LOTS and HOTS categories are presented. By replacing Bloom's taxonomy with Anderson and Krathwohl's taxonomy for developing the frameworks of core competence and basic competence, problems relate with the formulation of basic competence are solved and their indicators of achievement of competence (IPK) can be easily determined.

\section{REFERENCES}

[1] M. R. R. Kemp, J.E., G.R. Morrison, Designing Effective Instruction. New York: Macmillan College Publishing Company, 1991.

[2] R. . Mager, Preparing Instructional Objectives (2 edition). California: Pitman, 1984

[3] B. W. Tuckman, Measuring Educational Outcomes: Fundamentals of Testing. New York: Harcourt Brace Jovanovich, Inc, 1975.

[4] R. . Gagne, Essentials of Learning for Instruction. Hindsdale. Ill: The Dryden Press, 1974.

[5] K. RI, Peraturan Peraturan Menteri Pendidikan dan Kebudayaan Nomor 21 Tahun 2016 tentang Standar Isi Pendidikan Dasar dan Menengah Menteri Pendidikan dan Kebudayaan Republik Indonesia Nomor 24 Tahun 2016 tentang Kompetensi Inti dan Kompetensi Dasar Pelajaran pad. Indonesia, 2016.

[6] R. C. Bogdan and S. K.Biklen, Qualitative Research in Education: An introduction to theories and methods (5th ed.). Boston: Pearson, 2007.

[7] R. K. Yin, Case Study Research: Design and methods (3rd. ed.). Thousand Okas, CA: Sage Publications, 1994.

[8] S. Brookhart, How to Assess Higher Order Thinking Skills in Your Classroom. 2010

[9] S. dan R. E. Norris, Evaluating Critical Thinking. Pacific Grove, CA: Midwest Publications, 1989.

[10] S. Barahal, "Thinking about Thinking: Pre- Service Teachers Strengthen their Thinking Artfully," Phi Delta Kappan, vol. 90, no. 4, 2008.

[11] A. dan S. B. Nitko, Educational Assessment of Students. Pearson Merrill Prentice Hall, 2007.

[12] J. dan B. S. Bransford, ), The IDEAL Problem Solver. New York: W.H Freeman, 1984.

[13] B. . Bloom, Taxonomy of Educational Objectives Handbook 1 Cognitive Domain. New York: David McKay, 1956.

[14] L. W. Anderson and et al (Eds. . David R. Krathwohl, D. R., $A$ Taxonomy for Learning, Teaching, and Assessing: A Revision of Bloom's Taxonomy of Educational Objectives. Boston: MA: Allyn \& Bacon. (Pearson Education Group), 2001.

[15] Susanto, Telaah Kurikulum 2013 yang Telah Melalui Proses Pengembangan dan Perbaikan. Surabaya: Madrif Pustaka Production, 2016. 